\title{
PELATIHAN BERBAHASA INGGRIS DENGAN DRILLING DAN REPETITION BAGI KARANG TARUNA DESA JEDONG
}

\author{
Andy, Rusfandi, Lasim Muzammil \\ Pendidikan Bahasa Inggris, Fakultas Bahasa dan Sastra, Universitas Kanjuruhan Malang \\ andy@unikama.ac.id
}

\begin{abstract}
From the result of situation analysis and partner's problem, pengabdi (society service) team gives a solution to enlarge the opportunity for karang taruna (youth association) to be accepted to work upon the graduation of Vocational High School. The solution is formulated in the form of a workshop and coaching for karang taruna members (youth association) to practice English verbal proficiency by drilling and repetition method. At the end of this society service, the results are (1) Positive response and enthusiasm from youth association in Jedong village Wagir district. (2) Improved awareness of the benefit of English verbal proficiency. (3) Willingness to take a risk in participating. (4) Improved glossary, grammar, pronunciation, and spelling of verbal English and not ambiguous. (5) Improved chance to listen to native speaker's voice recording. (6) Improved chance to practice verbal English in the monologue (self-introduction), in pairs and mingle (talking in turns with all participants in a dynamic and fun/not boring atmosphere. (7) Learning media with $\mathrm{mp} 3$ native speaker voice recording becomes available. (8) Youth association members can be facilitated to listen to native speaker's voice recording, imitating and independent self-practice in their spare time. (9) Online webs become accessible to browse and download learning media files for future learning after this society service comes to its end.
\end{abstract}

Keywords: Drilling and Repetition, Improving Verbal English Proficiency.

\begin{abstract}
Abstrak
Dari hasil analisa situasi dan permasalahan yang dihadapi mitra, tim pengabdi memberi solusi guna memperbesar kesempatan bagi para anggota karang taruna untuk langsung diterima bekerja selepas menyelesaikan pendidikan di Sekolah Menengah Kejuruan. Adapun wujud solusinya, yaitu pelatihan dan pendampingan bagi para anggota karang taruna untuk berlatih berbahasa Inggris lisan dengan metode drilling dan repetition. Di akhir pengabdian ini, hasil yang diperoleh: (1) Respon positif dan antusias dari para anggota karang taruna desa Jedong Kecamatan Wagir. (2) Meningkatnya kesadaran akan perlunya penguasaan berbahasa Inggris lisan. (3) Bersedia mengambil resiko (risk-taking) dalam berpartisipasi. (4) Meningkatnya kosakata, tatabahasa, pengucapan dan pelafalan berbahasa Inggris lisan dan tidak ambigu. (5) Bertambahnya kesempatan mendengarkan suara rekaman penutur asing. (6) Bertambahnya kesempatan berlatih berbahasa Inggris lisan secara individu/monolog (self-introduction), secara berpasangan dan secara bergantian dengan seluruh peserta dalam situasi yang dinamis dan menyenangkan/tidak membosankan. (7) Tersedianya media belajar suara penutur asing berupa rekaman mp3. (8) Para anggota karang taruna terfasilitasi untuk mendengarkan suara penutur asing, menirukan dan berlatih secara mandiri di waktu luang mereka. (9) Tersedianya situs online untuk mengakses dan mengunduh file media belajar di waktu mendatang setelah pelatihan dan pendampingan berakhir.
\end{abstract}

Kata Kunci: Drilling dan Repetition, Meningkatnya Kemampuan Berbahasa Inggris Lisan. 


\section{PENDAHULUAN}

\section{Analisa Situasi}

Penguasaan kemampuan berbahasa Inggris menjadi nilai tambah dan keharusan utamanya di dunia kerja nyata yang menuntut tingkat persaingan bisnis yang cukup tinggi, sehingga wawasan, peluang, koneksi dan mitra bisnis diupayakan seluas mungkin baik di dalam dan luar negeri. Sehubungan dengan ini, penerimaan karyawan baru lebih mengutamakan fresh graduate dengan kemampuan yang siap pakai di dunia kerja, salah satunya yaitu berbahasa Inggris utamanya lisan. Dengan keterampilan berbahasa Inggris lisan, pegawai baru dapat berkontribusi langsung untuk mengambil peluang bisnis baru yang tersedia juga memperluas pasar sesuai dinamika tuntutan dunia bisnis yang dinamis; menyesuaikan perkembangan teknologi yang tak terpisahkan dari komunikasi global-kebanyakan menggunakan bahasa Inggris sebagai media komunikasi.

Pentingnya penguasaan keterampilan berbahasa Inggris lisan mendorong diaplikasikannya metode pengajaran dan pembelajaran drilling dan repetition yang menyenangkan, memotivasi, mengundang keinginan dan kesadaran untuk berlatih dan praktek berbahasa Inggris lisan juga tidak membosankan namun efektif dalam meningkatkan berbagai aspek keterampilan berbahasa Inggris lisan meliputi kosakata, tata bahasa, pengucapan dan pelafalan sehingga tidak menimbulkan salah penafsiran dan menghambat kelancaran berkomunikasi.

Hasil penelitian dari Yoshida dan Fukada (2014) menyatakan bahwa model rekaman suara yang ditirukan (repeat-after-the-model), mendorong pelajar untuk lebih menguasai intonasi/penekanan pengucapan bahasa
Inggris tanpa adanya petunjuk/instruksi secara eksplisit dari pengajar. Pelajar diajak belajar seperti ketika belajar bahasa Ibu mereka, yaitu dengan menyerap cara berbahasa yang wajar sesuai konteks penggunaannya sebagaimana bahasa itu digunakan oleh para penutur aslinya. Peran pengajar hanyalah mendampingi dan membimbing, dengan berkurangnya keharusan pengajar untuk secara terperinci meminta pelajar menirukan model rekaman suara secara tepat dan dengan kesalahan seminimal mungkin. Manfaat tambahan dari metode drilling and repetition nampak pada pengabdian oleh Wijayatiningsih, Mulyadi dan Fathurrohman (2015) yang menyatakan bahwa metode ini dapat mendorong warga desa untuk termotivasi dalam berpartisipasi pada latihan berbahasa Inggris lisan. Hal ini berdampak dapat mengembangkan desa wisata mereka dengan mendorong program homestay.

Persaingan bisnis yang ketat membuat beberapa pabrik gulung tikar, ini berdampak pada besarnya pemutusan hubungan kerja di lokasi sekitar pabrik. Dampak nyata yaitu jumlah pengangguran yang meningkat, juga berkurangnya lowongan pekerjaan bagi para pencari kerja baru dengan modal pendidikan minimal (belum sarjana). Keadaan ini akan memberi dampak besar bagi suatu wilayah, dimana sebagian besar penduduknya mengandalkan bekerja di pabrik di lokasi tempat tinggal mereka. Para penduduknya menjadi terfokus untuk langsung terjun ke dunia kerja, dengan sedikit minat untuk menempuh pendidikan di bangku sekolah. Lulus Sekolah Menengah Pertama (SMP) terkadang dirasa cukup, dan mereka didorong untuk langsung terjun ke dunia kerja dan secara instan mendapatkan penghasilan. Hal ini bertolak belakang dengan tuntutan 
Andy, dkk. Pelatihan Berbahasa Inggris Dengan Drilling Dan ...

dunia kerja, dimana persyaratan penerimaan pegawai baru kebanyakan mensyaratkan lulusan Sekolah Menengah Atas (SMA) bahkan sarjana dengan tambahan keterampilan tambahan seperti berbahasa Inggris. Konsekuensinya, penduduk di lokasi seperti ini akan memiliki kesempatan kecil untuk memenangkan kompetisi dalam dunia kerja. Bahkan, dapat terlewatkan kesempatan emas untuk dapat memperbaiki taraf penghidupan mereka ke tingkat lebih tinggi, dengan bekerja di sektor yang menuntuk tingkat pendidikan minimal sarjana juga menguasai keterampilan khusus.

Dengan kondisi pada masyarakat di lingkungan yang terfokus pada terjun langsung ke dunia kerja dengan persiapan yang minimalis, sehingga dunia kerja dengan taraf kesejahteraan rendah yang dapat mereka geluti. Pengabdian masyarakat ini melibatkan anggota karang taruna di desa Jedong kecamatan Wagir, yaitu dengan melatih dan mendampingi agar dapat meningkatkan keterampilan berbahasa Inggris lisan. Dengan memiliki keterampilan ini, kesejahteraan mereka menjadi lebih baik dan meningkat.

\section{Permasalahan}

Dari hasil wawancara dan berdiskusi dengan para tokoh masyarakat dan mitra, juga melakukan observasi keseharian kehidupan masyarakat desa Jedong didapat beberapa permasalahan sebagai berikut: (1) Minimnya nilai tambah yang menjual ketika masuk persaingan dunia kerja. (2) Rendahnya kesadaran dan kemauan untuk meningkatkan keterampilan dan kemahiran khusus (berbahasa Inggris). (3) Terbatasnya kesempatan dan sarana pendukung untuk mengasah keterampilan, dalam bentuk pelatihan khususnya berbahasa Inggris lisan. (4) Tidak tersedianya materi dan media belajar yang memfasilitasi pembelajaran yang efektif, juga dapat memaksimalkan waktu luang dengan belajar secara mandiri dan terarah. (5) Hilangnya meraih peluang kerja dikarenakan akses yang terbatas dengan kendala bahasa Inggris.

\section{Solusi yang ditawarkan}

Setelah dilakukan analisa situasi

dan kebutuhan guna membantu mengatasi permasalahan mitra, diberikan solusi untuk dapat membekali para anggota karang taruna agar terampil dan mahir berbahasa Inggris lisan sebagai berikut: (1) Mensosialisasikan keuntungan dari menyelesaikan pendidikan sampai tingkat sarjana disertai dengan keterampilan dan kemahiran khusus. (2) Mengenalkan materi ajar yang menyenangkan dan menarik sehingga peserta menjadi tergugah, termotivasi dan antusias untuk terlibat secara dinamis. (3) Dilaksanakannya pelatihan dan pendampingan dengan mengenalkan metode drilling dan repetition di lokasi yang sesuai keinginan peserta (4) Dibuatkan modul ajar dan rekaman dalam bentuk mp3 yang dapat digunakan untuk menyampaikan dan melatih metode drilling dan repetition selama dan setelah proses pelatihan dan pendampingan. (5) Dikenalkannya media dan alamat situs internet juga cara yang mudah untuk mengakses informasi guna membaca dan mencari peluang yang ada, meski dengan kemampuan bahasa Inggris yang masih terbatas.

\section{METODE PELAKSANAAN}

Kegiatan pengabdian ini dilakukan di Bumi Mas Indah Blok W.1 / 03 RT 05 RW 07 desa Jedong 
kecamatan Wagir Kabupaten Malang. Sasaran kegiatan adalah anggota karang taruna yang kebetulan bersekolah di tingkat awal Sekolah Menengah Kejuruan (SMK), para orang tua menyekolahkan putri mereka di bidang vokasi agar cepat terserap lowongan dunia kerja setelah lulus kelak.

Permasalahan pengangguran yang muncul dan meningkatnya jumlah pencari kerja, solusi yang ditawarkan untuk mengatasi adalah meningkatkan nilai jual para warga desa dengan terampil berbahasa Inggris secara komunikatif. Warga yang semula merasa asing dengan bahasa Inggris, mulai tertarik untuk berlatih secara aktif dan mencoba berkomunikasi dalam bahasa Inggris. Mereka dapat mengetahui pengucapan yang baik dan benar juga melatihnya baik secara berpasangan maupun dalam kelompok. Dengan metode belajar Drilling and Repetition, para warga desa dapat menirukan pengucapan yang benar mendekati ucapan dari penutur asing dan tidak menimbulkan kesalahpahaman. Manfaat dari menirukan model ucapan (repeat-afterthe-model) dari latihan kosakata seperti dikatakan oleh Yoshida dan Fukada (2014) berguna dalam memfasilitasi para pelajar menguasai intonasi/penekanan pengucapan kata tanpa instruksi secara eksplisit. Lebih lanjut, manfaat nyata dari metode drill dan repetition diungkapkan oleh Wijayatiningsih, Mulyadi dan Fathurrohman (2015) yang mana dapat memotivasi para warga desa untuk praktek dan berlatih berbahasa Inggris guna mengembangkan homestay di desa wisata.

Para warga desa mampu mengembangkan kemampuan mereka dalam pemantapan, dengan format ajar sama namun dengan kondisi dan situasi yang berbeda. Misal ketika mereka sudah paham bertegur sapa dengan teman dan kelompok mereka, kemudian diperluas dengan ketika bertemu orang asing. Hal ini menambah lingkup pertemanan mereka juga wawasan tentang berbagai hal.

Alur dalam dalam pengabdian dan pendampingan ini adalah sebagai berikut:

(1) Dibuat jadwal rutin pelatihan pengabdian dan pendampingan, dengan ketentuan setiap kali pelatihan diwajibkan membawa modul ajar yang telah disediakan.

(2) Ketua dan para anggota pengabdi memberikan demonstrasi pengucapan yang baik dan benar bahasa Inggris, dimulai dengan kosakata.

(3) Gambar dari kosakata yang dimaksud ditampilkan dalam lembaran print out, sehingga warga desa dapat dengan jelas menangkap kosakata yang dimaksud (contoh worker dengan gambar para pekerja/buruh).

(4) Diputarkan suara pengucapan oleh penutur asing dari kosakata yang dimaksud.

(5) Ketua dan para anggota pengabdi membagi kelompok warga desa dalam kelompok agar mengulangulang (drilling) dan berlatih pengucapan yang baik dan benar.

(6) Tahap berikutnya, para warga desa didorong untuk berlatih secara berpasangan. Pada tahap mendekati akhir dari pengabdian dan pendampingan, para warga desa secara individu mampu berkomunikasi dalam bahasa Inggris secara lebih percaya diri dan mampu mengembangkan diri untuk membuka peluang belajar secara mandiri.

(7) Dari aktifitas pengabdian dan pendampingan ini menghasilkan transfer teknologi seperti yang 
Andy, dkk. Pelatihan Berbahasa Inggris Dengan Drilling Dan ...

terlihat pada Gambar 1 oleh Andy, dkk (2017).

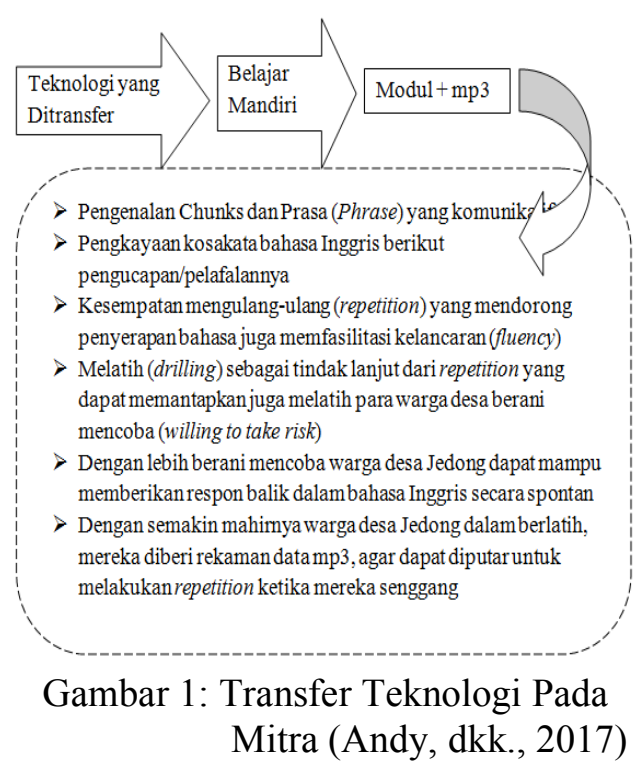

HASIL DAN PEMBAHASAN

Pelaksanaan kegiatan ini dilaksanakan selama satu bulan untuk kegiatan pendampingan dan pelatihan bahasa Inggris dengan drilling dan repetition, bagi para anggota karang taruna. Adapun pelaksanaan pelatihan dimulai dari tanggal 8 Juli sampai dengan 12 Agustus 2017. Kegiatan pengabdian masyarakat dapat diterima dengan baik dan berjalan lancar, meski dengan sedikit penyesuaian jadwal mengingat para anggota karang taruna banyak disibukkan dengan berbagai lomba memperingati kemerdekaan Indonesia selama bulan Agustus.

Dalam kegiatan ini, 5 sampai 10 anggota karang taruna ikut serta (bergantian karena kesibukan menjadi panitia lomba hari kemerdekaan selama bulan Agustus), mayoritas perempuan berumur 13-15 tahun, sedang duduk di kelas 9 (SMP), MAN, kebanyakan sedang menempuh studi di Sekolah Menengah Kejuruan (SMK) di kota Malang. Hal ini menunjukkan usia ratarata peserta kegiatan ini berada di akhir masa studi mereka, kebanyakan tidak melanjutkan ke bangku kuliah dan memilih langsung terjun ke dunia kerja. Aktivitas ini bisa dilihat pada Gambar 2.

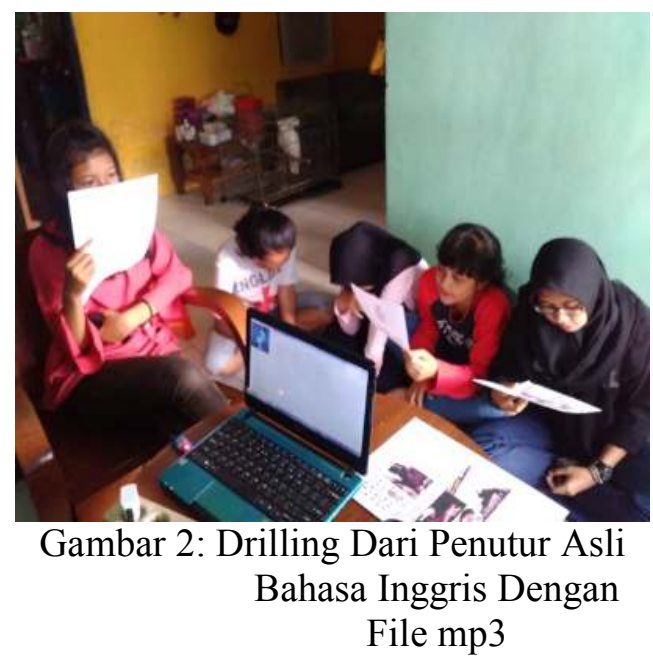

Hasil respon menunjukkan bahwa kebanyakan peserta menyatakan belum pernah ada pangabdian masyarakat dan KKN di tempat mereka juga pendampingan dan pelatihan bahasa Inggris. Melihat kondisi ini, diperkenalkan metode drilling dan repetition. Sesi 1 dengan melihat modul ajar tentang materi yang akan disampaikan (English alphabeth, self introduction, greetings, interview, like dan don't like), sesi 2 pengabdi memberi model pengucapan dan pelafalan lalu peserta mengikuti (repetition) kemudian diulang berkalikali (drilling), sesi 3 rekaman audio suara penutur asing (native speakers) diputarkan dan diikuti oleh seluruh peserta kemudian secara bergantian secara individu mengulang suara audio, sesi 4 permainan (game) bisa dengan melempar bola secara acak dalam menyebutkan huruf-huruf dalam bahasa Inggris juga mengeja kosa-kata, sesi 5 melakukan bermain peran (role play) dalam wawancara secara berpasangan diikuti mingle tentang kesukaan dari 
masing-masing peserta. Kegitan Pendampingan pada Gambar 3 ini dilakukan berulang-ulang sampai peserta bisa melakukan belajar mandiri tanpa bersama-sama dengan tutor lagi.

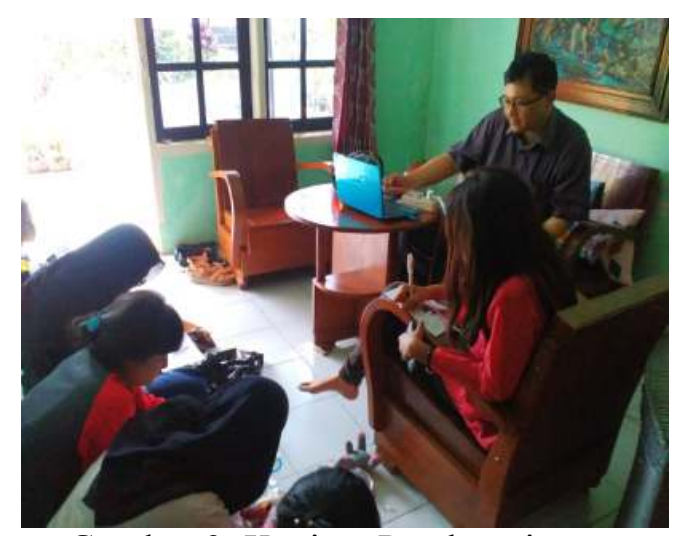

Gambar 3: Kegitan Pendampingan

Berdasarkan hasil angket, sebagian besar peserta sebelum kegiatan ini merasa bahasa Inggris sulit, belum menemukan cara praktis dalam belajar dan belum pernah mengikuti pelatihan bahasa Inggris diluar pelajaran sekolah, juga telah maksimal dalam belajar, sehingga mereka merasa kegiatan ini dibutuhkan di tempat mereka.

Setelah kegiatan bagaimanapun juga peserta merasa metode drilling dan repetition sangat membantu mengasah bahasa Inggris lisan khususnya dalam meningkatkan kosakata, tatabahasa, pengucapan dan pelafalan. Selama kegiatan, mereka merasa metode ajar ini telah dilaksanakan dengan baik dan memperkaya penguasaan bahasa Inggris mereka sehingga mereka menyatakan kegiatan ini perlu ditindaklanjuti secara berkesinambungan. Mengingat sebagian besar peserta masih duduk di bangku sekolah, mereka banyak terbantu dalam mengingat kembali pelajaran bahasa Inggris yang didapat di sekolah dan memperdalam penguasaan sehingga dapat menumbuhkan rasa percara diri.

Berikut adalah hasil angket dari masyarakat desa Jedong Kec. Wagir:
(1) Mengingat kembali materi ajar (pengucapan dan kosakata) yang didapat sebelumnya.

(2) Memperkaya penguasaan kosakata baru.

(3) Memantapkan pengucapan dan pelafalan berbahasa Inggris lisan sesuai model penutur asing (native speakers).

(4) Meningkatkan percaya diri dan kelancaran berbicara dalam bahasa Inggris secara individu, berpasangan juga kelompok.

(5) Memiliki kesempatan berlatih dan mengasah berbahasa Inggris secara interaktif dan dinamis baik secara berpasangan maupun kelompok.

(6) Mampu memperkenalkan diri dalam bahasa Inggris sebagai bekal mengikuti wawancara (interview) kerja.

(7) Memiliki rekaman audio file sebagai bahan berlatih secara mandiri selesai pelatihan dan pendampingan ini

\section{SIMPULAN}

Pengabdian dan pendampingan ini dapat disimpulkan bahwa, pertama, bisa menumbuhkan rasa nyaman berbahasa Inggris, memperkaya kontak dan stimulus bahasa Inggris lisan dengan model penutur asing, mengulang dan memperdalam pelajaran sekolah, mengkondisikan praktek berlatih bahasa Inggris lisan baik secara individu (pengenalan diri sendiri), berpasangan (wawancara), juga berkelompok (class survey). Kedua, dengan melalui observasi nampak bahwa para peserta yang semula merasa canggung, kikuk ketika dikondisikan meluangkan waktu khusus berlatih berbahasa Inggris menjadi lebih nyaman dalam mengikuti juga terbangun kesadaran dan kebutuhan mengikuti pelatihan dan pendampingan 
Andy, dkk. Pelatihan Berbahasa Inggris Dengan Drilling Dan ...

ini. Kepekaan terbangun akan ketepatan pengucapan bahasa Inggris sesuai model pengucapan penutur asing (native speakers), para peserta dapat mengulang kembali bahkan memantapkan pengusaan bahasa Inggris lisan juga dapat mengasah kelancaran dalam komunikasi yang dinamis dan interaktif.

Akhirnya, tersedianya materi dan metode pembelajaran yang menjadi terfasilitasi baik selama pelatihan dan pendampingan maupun setelahnya sehingga target transfer teknolgi kepada mitra terpenuhi karena kesempatan untuk berlatih mandiri tanpa tutor sangat luas yang bisa dilakukan sendiri di rumah masing-masing. Disarankan kepada pelaksana pengabdian lain untuk memperhatikan perbedaan teknologi yang bisa ditransfer selain ilmu sosial humaniora. Demikian juga terhadap Lembaga Pengabdian pada Masyarakat (LPPM) supaya tetap memberikan kesempatan yang seluas-luasnya kepada para dosen untuk melakukan pengabdian kepada masyarakat sehingga bisa melakukan Tri-Dharma Perguruan Tinggi dengan baik. Dan pada akhirnya, bagi masyarakat desa Jedong peserta pelatihan dan pendampingan supaya tetap berlatih secara mandiri dengan modul ajar dan rekaman file audio mp3 yang sudah diberikan sehingga proses belajar menguasai bahasa Inggris secara lisan ini bisa berlanjut walaupun pelatihan dan pendampingan sudah selesai dilaksanakan.

\section{UCAPAN TERIMA KASIH}

\footnotetext{
Disampaikan terima kasih yang tak terhingga kepada LPPM Universitas Kanjuruhan Malang, Fakultas Bahasa dan Sastra, Program Studi Pendidikan Bahasa Inggris dan masyarakat Bumi Mas Indah Blok W.1
}

/ 03 RT 05 RW 07 desa Jedong kecamatan Wagir kabupaten Malang yang karena mereka kegiatan ini bisa terlaksana.

\section{DAFTAR PUSTAKA}

Andy, Rusfandi, \& Muzammil, L. (2017). Model Pembelajaran Drilling dan Repetition Bagi Masyarakatdesa Jedong Kecamatan Wagir. Prosiding Seminar Nasional Pengabdian Masyarakat LPPM-Universitas Kanjuruhan Malang, 30 Agustus 2017 (pp. 117-121). Bisa diakses di https://semnas.unikama.ac.id/ lppm/prosiding/2017/Pengabdia $\mathrm{n} / 19$. Andy Pengabdian Pendidi kanBahasaInggris.pdf.

Wijayatiningsih, T. D., Mulyadi, D., \& Fathurrohman, A. (2015). Drill dan Repetition Dalam Pelatihan Bahasa Inggris Pemilik Homestay Desa Wisata Kandri Semarang. The 2nd University Research Coloquium 2015 ISSN 2407-9189.

Yoshida, K. \& Fukada, A. (2014). Effects of Oral Repetition on Learners' Japanese Word Accentuation. IALLT Journal of Language Learning Technologies. 44 (1). 